\title{
A new method for the cytological examination of the cerebrospinal fluid
}

\author{
RUNE SÖRNÄS \\ From the Department of Neurology, University of Lund, Sweden .
}

Several methods for routine cytological examination of the cerebrospinal fluid (C.S.F.) have been published. In 1904 Fuchs and Rosenthal introduced a method for counting the number of cells per $3 \cdot 2 \mathrm{c} . \mathrm{mm}$. with differentiation between mononuclear and polynuclear cells. This method, however, yields but little cytological information, especially if the C.S.F. is poor in cells. Various procedures for concentrating, fixing, and staining have been tried in an attempt to obtain cellular preparations allowing a detailed morphological study in the same way as in blood films. However, all of these techniques have proved unsatisfactory in one respect or another with the result that the Fuchs-Rosenthal method is still the one most widely used. There is thus need of a better method for routine clinical use. Such a method should be technically simple, rapid, gentle, and give a high cell yield. After concentration of the sample it should be possible to identify the cells, which should be a representative sample of the cell population, i.e., allow a reliable differential cell count. A method satisfying these requirements and suitable for routine use is described below.

\section{METHOD}

SEDIMENTATION TECHNIQUE One end of a glass cylinder,

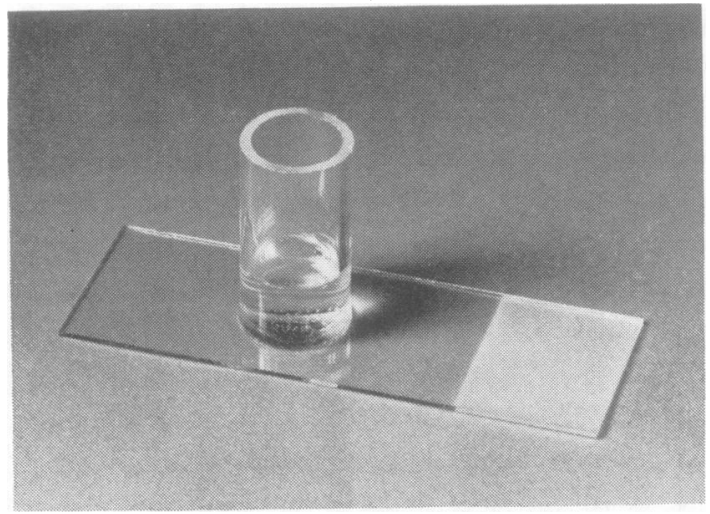

FIG. 1. The glass cylinder fixed on the slide.
$4 \mathrm{~cm}$. long with an inner diameter of $1 \mathrm{~cm}$., is immersed in liquid Vaseline and applied immediately to a clean, fat-free slide. When the Vaseline cools and sets, it fixes the cylinder to the slide. Then $0.7 \mathrm{ml}$. of fresh C.S.F. is deposited in the cylindrical chamber (Fig. 1). The height of the column of the sample is about $6 \mathrm{~mm}$. A lymphocyte sediments at the rate of about $1 \mathrm{~mm} . / 10 \mathrm{~min}$. (Eneström, 1965). After the column has been allowed to stand for one hour at room temperature, it may be assumed that the bulk of cells have reached the bottom of the chamber. The sedimentation period was limited to one hour also because the cells begin to degenerate and die after this period. After one hour, the supernatant is sucked off with a Pasteur pipette. During the withdrawal the tip of the pipette is kept just under the surface of the liquor at the cylinder wall, slowly following the downward movement of the fluid. The supernatant is removed carefully to obtain the lowest possible loss of cells. About $0.2 \mathrm{ml}$. of the fluid is left and the cylinder is removed from the slide, leaving behind a ring of Vaseline enclosing the residual fluid and the sedimented cells on the slide. The preparation is then examined in a phasecontrast microscope with a water immersion lens (obj. $40 / 0 \cdot 75 \mathrm{~W}$ ). If the cells are to be studied for a considerable time, C.S.F. should be added in suitable volumes to prevent dehydration.

STAINING PROCEDURES The sedimented cells are routinely stained by the method of May-Grünewald-Giemsa. This procedure is chosen because it uses 'dry' fixation, which gives a better yield of cells than methods using 'wet' fixation. After the cells have been examined in the phasecontrast microscope all the supernatant fluid is absorbed uninterruptedly with the tip of a piece of blotting paper held over the centre of the preparation, which thus dries from the periphery inwards. The small amount of residual fluid along the Vaseline ring is sucked up and the Vaseline then scraped off. The quicker the preparation is dried the better it stains. The cells are then stained for three minutes with May-Grünewald's solution, rinsed in distilled water, and counterstained for five minutes in a Giemsa solution ( 5 drops of Giemsa original solution to $15 \mathrm{ml}$. of distilled water). The slide is then rinsed in distilled water, airdried, washed in Xylene, and mounted in Eukitt ${ }^{1}$.

YIELD OF SEDIMENTATION METHOD The yield obtained by the method was estimated from the results obtained with C.S.F. samples containing 4-94 cells per $10 \mathrm{c} . \mathrm{mm}$. ${ }^{2}$ O. Kindler, Freiburg, Germany. 
but no blood cells. The samples were thoroughly shaken to secure as even a suspension as possible. On each sample the total number of cells in $0.7 \mathrm{ml}$. of C.S.F. was estimated from the mean of cell counts in twenty $10 \mathrm{c} . \mathrm{mm}$. Jessen chambers. The counts were performed on undiluted C.S.F. by the use of phase contrast. With the sedimentation method described $0.7 \mathrm{ml}$. of each sample was studied. After the cells had sedimented all those within the Vaseline ring on the slide were counted in phase contrast. After staining with May-Grünewald-Giemsa all the identifiable cells were again counted. The ratio between the number of sedimented cells and the calculated number in $0.7 \mathrm{ml}$. of C.S.F. gives the yield obtainable by the sedimentation method and is expressed as a percentage. The yield obtained after staining of the preparation was calculated in the same way. The mean, standard deviation, and confidence limits of the mean at $5 \%$ confidence were calculated from the values obtained for 30 C.S.F. samples.

QUALITATIVE RELIABILITY AND REPRESENTATIVITY OF THE SEDIMENTATION METHOD The study was performed on C.S.F. samples from patients with neurological diseases. Neither the distribution of the total cell counts nor the relative numbers of the different types of cells can $a$ priori be expected to be normal. In an attempt to assess the accuracy of the differential cell count four aliquots of each of the C.S.F. samples from 19 patients were allowed to sediment simultaneously and the differential counts were determined for 100 cells in each aliquot. Of the four differential cell counts on each sample two were performed by the author and two by his assistant, Mrs. Sjögren. The samples were found to contain 4-600 leucocytes per 10 c.mm.

To test the reliability of the method the macrophages were chosen, because they showed the widest variation of the four types of cell studied-macrophages, monocytoids, lymphocytes, and neutrophils. The mean percentage $(P)$ of the macrophages of the four counts was calculated for each patient. Using the formula $\mathrm{S}=\sqrt{\frac{\mathrm{P}(\mathrm{P}-100)}{\mathrm{n}}} \quad \frac{3}{4}$, where $\mathrm{n}$ denotes the number of cells, in this case 100 , a 'theoretical' distribution was calculated from this material. To assess the variability the deviations, expressed in $\mathbf{S}$ units, of the four individual values in each patient from the mean value were noted and classified. The factor $3 / 4$ in the formula for $\mathrm{S}$ was introduced for the reason that the deviations were calculated from a mean value of four observations. These standardized deviations ought to be normally distributed with mean value $=0$ and standard deviation $=1$. The number of frequencies in the entire material belonging to each group classified in this way was calculated and then tested against the expected number in each group, calculated under the assumption of a normal distribution. Degrees of freedom $=3$.

To ascertain whether the differential cell count obtained from the sedimented cells examined in the phasecontrast microscope reflected the true distribution of the cells, C.S.F. samples from 37 patients with $10-1,500$ leucocytes per $10 \mathrm{c} . \mathrm{mm}$. and at most 50 erythrocytes per
10 c.mm. were selected for study. A differential cell count was made by the author of an undiluted aliquot of each sample in Jessen chambers with the aid of phase contrast. One hundred cells were counted. This count was assumed to reflect the true distribution of the cells. A differential cell count was then made by the author's assistant of the sedimented cells in $0.7 \mathrm{ml}$. of C.S.F. One hundred cells were counted. The means of percentages (P) of the macrophages, monocytoids, and lymphocytes, respectively, before and after sedimentation, were calculated and from these means a 'theoretical' spread of the differences between the percentages of each type of cell before and after sedimentation was calculated according to the formula: $S=\sqrt{\frac{2 \mathrm{P}(100-\mathrm{P})}{\mathrm{n}}}$, where $\mathrm{n}$ denotes the number of cells, in this case 100 . The factor 2 in the formula for $\mathbf{S}$ was introduced for the reason that we are calculating with differences between two percentages, each with a standard deviation of $\sqrt{\frac{P(100-P)}{n}}$. The differences were expressed in $S$ units. The number of frequencies in the entire material belonging to each group classified in this way was calculated and then tested against the expected number in each group, calculated under the assumption of a normal distribution. Degrees of freedom $=3$.

In the present work the $\chi^{2}$ test was used for testing significance with the null hypothesis that there was no difference between the observed and expected frequencies.

\section{RESULTS}

EXAMINATION OF NATIVE CELLS IN PHASE-CONTRAST MICROSCOPE A differential cell count is made of macrophages, monocytoids, lymphocytes, neutrophils, eosinophils, cells that have phagocytosed erythrocytes (erythrophages), cells that have phagocytosed haemosiderin or haematoidin, and of atypical cells. One hundred cells are counted.

Typical macrophages are readily recognized (Figs. 2 and 3). The cytoplasm is voluminous, well outlined, and often containing vacuoles and perinuclear granules. The nucleus is round, oval, or kidney-shaped, and has a loose chromatin network and a distinct nuclear membrane. In some macrophages the cytoplasm is only diffusely outlined or is divided into long 'ragged' extensions. Sometimes the density of the nucleus coincides with that of the cytoplasm and then it is not possible to distinguish the nucleus with certainty.

Cells that have phagocytosed erythrocytes, haemosiderin, or haematoidin are easily identified. The haemosiderin is seen as irregular, yellow-brown lumps (Fig. 6), the haematoidin as rhomboid, yellow-brown crystals.

The monocytoids occur in various shapes. Some are round and well defined, resembling lymphocytes, 

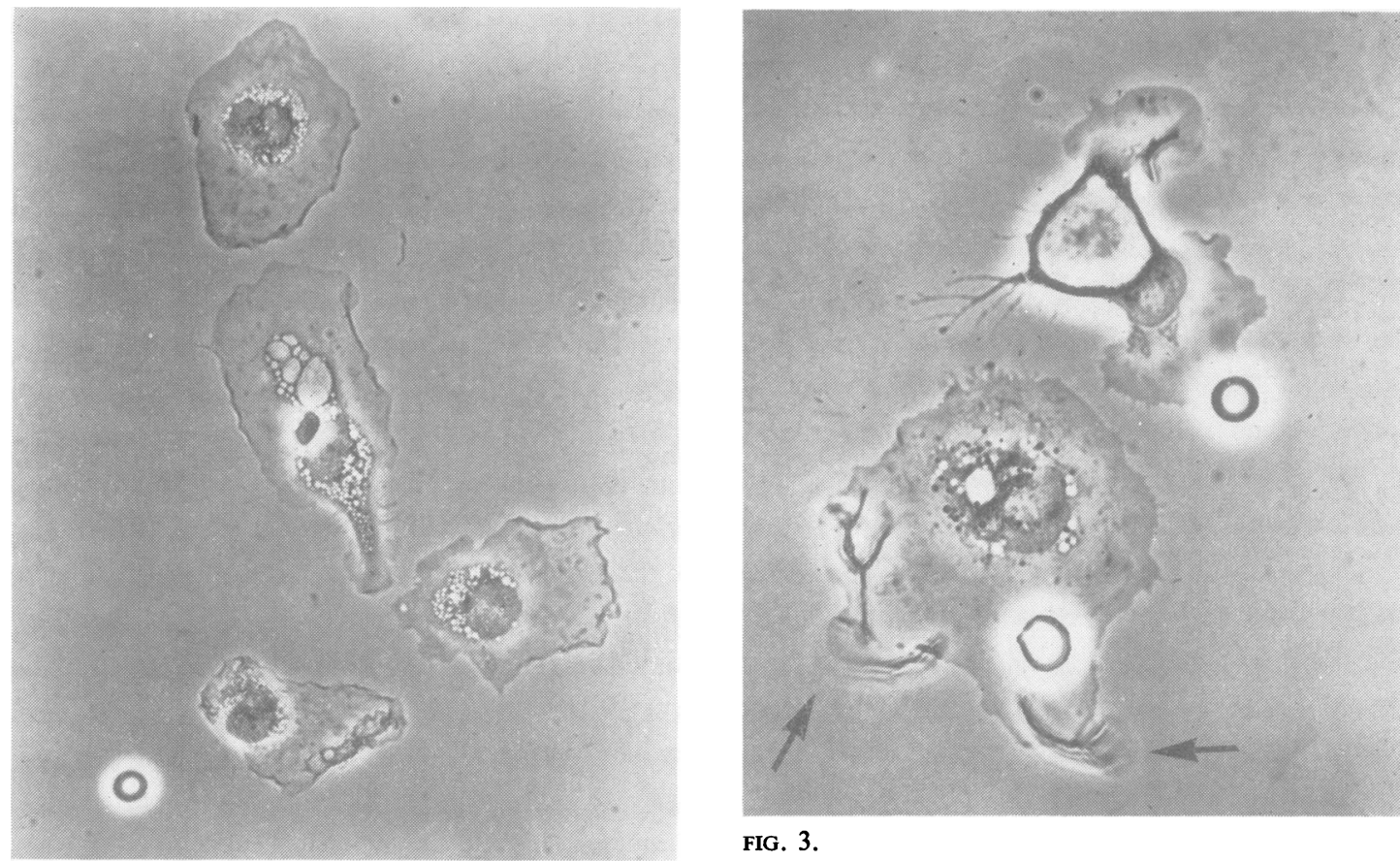

FIG. 3.

FIG. 2 .

FIG. 2. Typical macrophages with perinuclear vacuoles and small granules (phase contrast $\times 1,350$ ).

FIG. 3. Two macrophages in an active stage. One macrophage has formed a large vacuole. The cytoplasm of the other 07 is partly blurred (arrows) because of the rapid movement of the cytoplasm during the exposure, 5 sec. (phase contrast $\times 2,700)$.
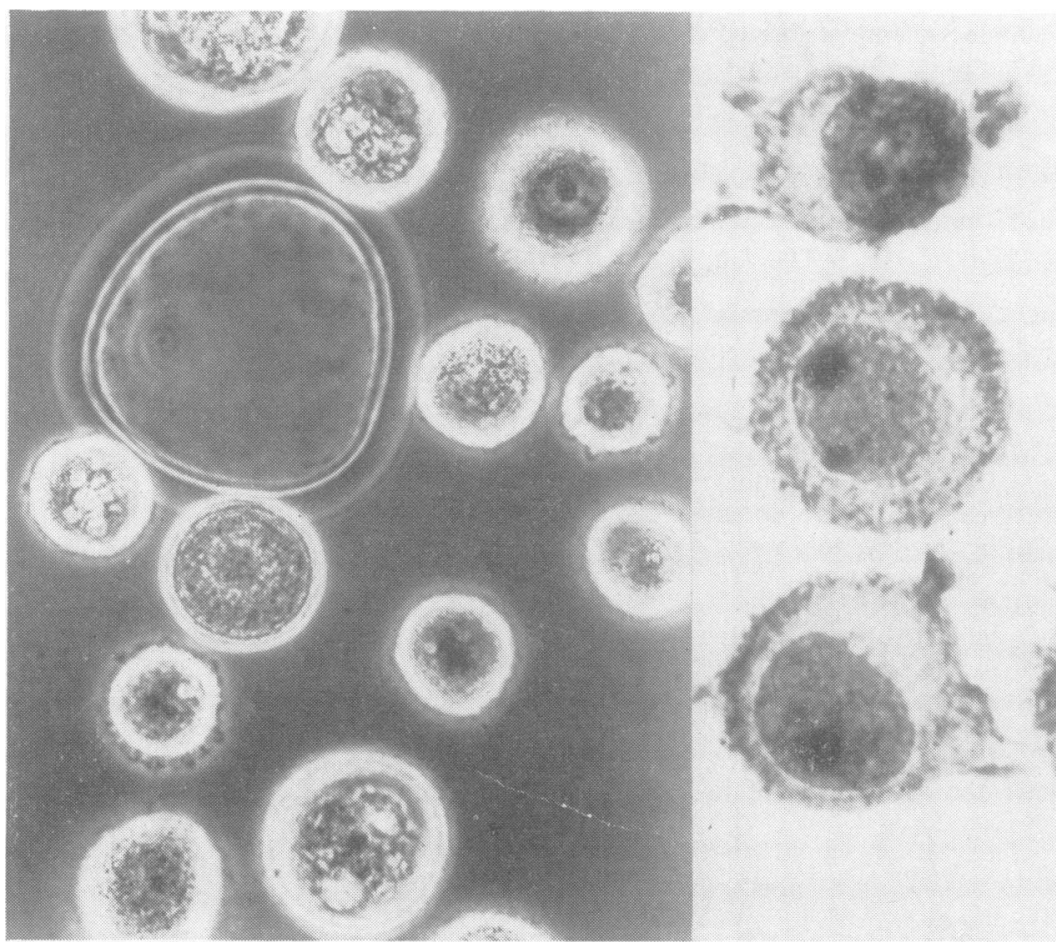

FIG. 4.
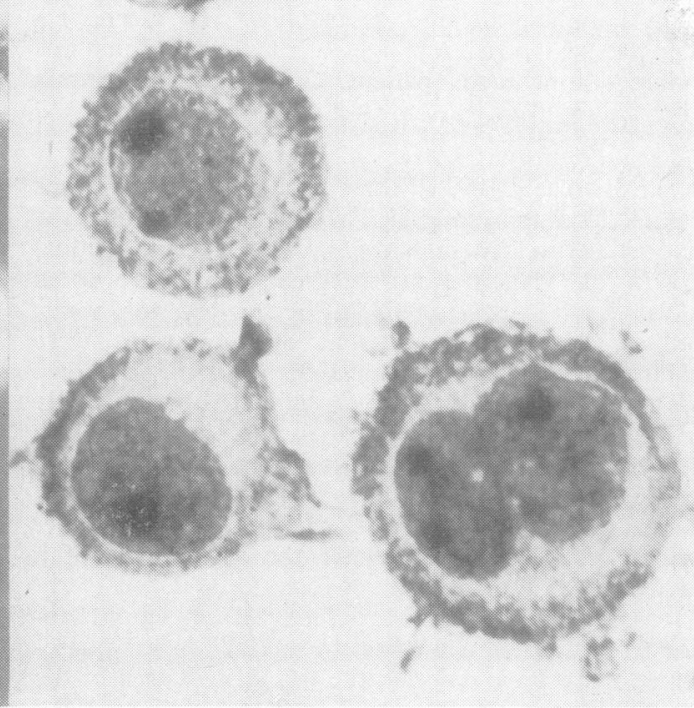

FIG. 5 .

FIG. 4. Exfoliated malignant cells from a case of mammary cancer with meningeal carcinomatosis. The largest cell is a monocytoid. In stained preparations it has a signet-ring-cell-like appearance (phase contrast $\times 1,800)$.

FIG. 5. The same cells as in Fig. 4 stained by May-Grünewald-Giemsa $(\times 4,460)$. 


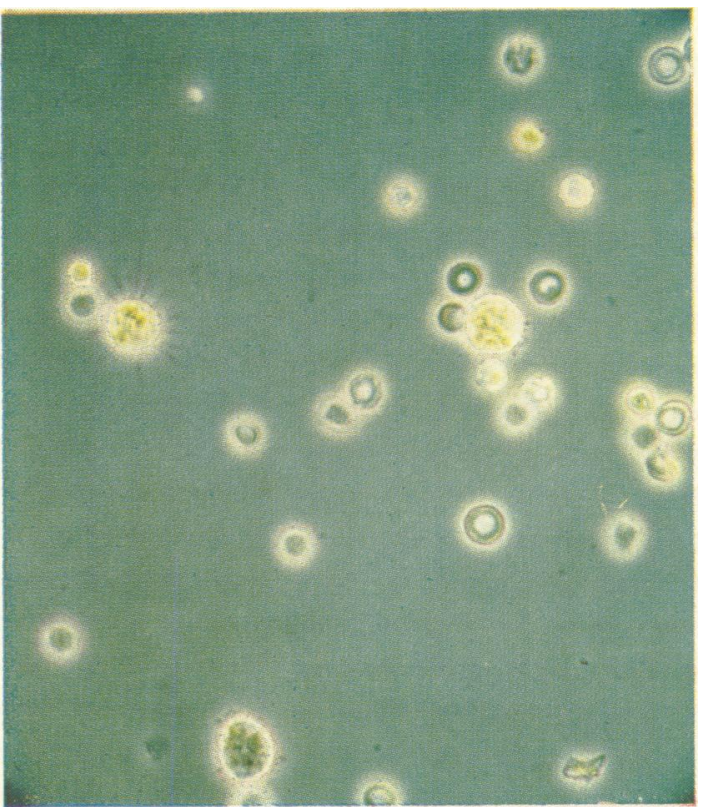

FIG. 6.

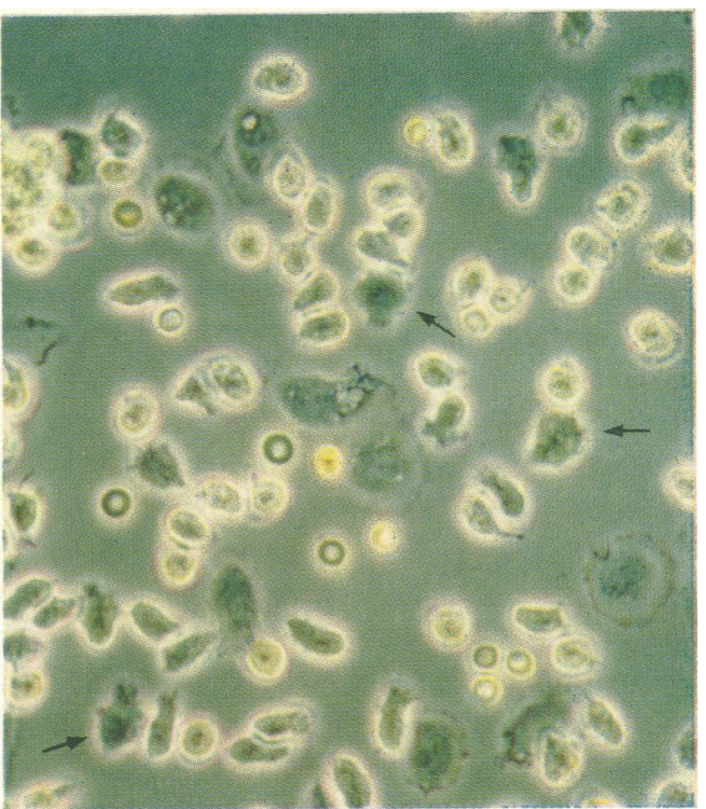

FIG. 7.

FIG. 6. Three cells having phagocytosed haemosiderin. One of them has fine cytoplasmic extensions. There are also some l ymphocytes and erythrocytes ( phase contrast $\times 1,600)$.

FIG. 7. Cell reaction in a case of intracerebral haematoma. Round and pyriform neutrophils dominate. In some of the pyriform types the tapering part is slit up or tail-like. In this reproduction of the original colour photograph the neutrophils have a greenish tint. In reality they are slightly yellow, the pyriform type only around the edge. Three degenerated neutrophils with a 'speckled' appearance are seen (arrows). In the centre are two macrophages. There are a few monocytoids and erythrocytes but no lymphocytes (phase contrast $\times 1,600)$.

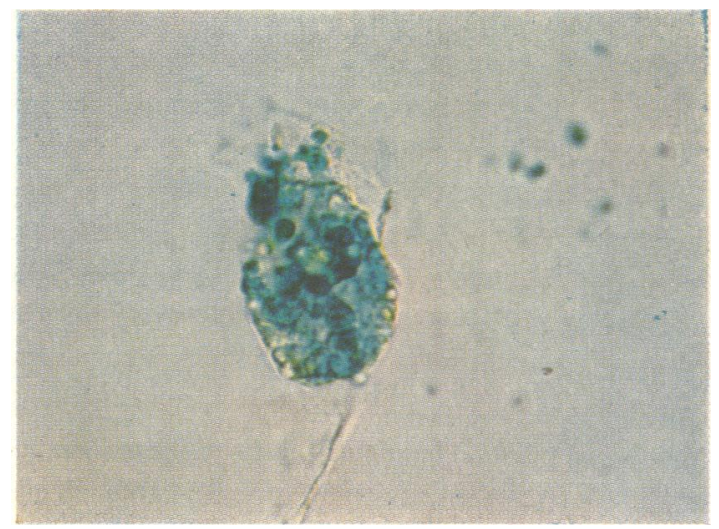

FIG. 8. A cell from the sample shown in Fig. 6, stained for iron with Berlinerblau $(\times 400)$. 


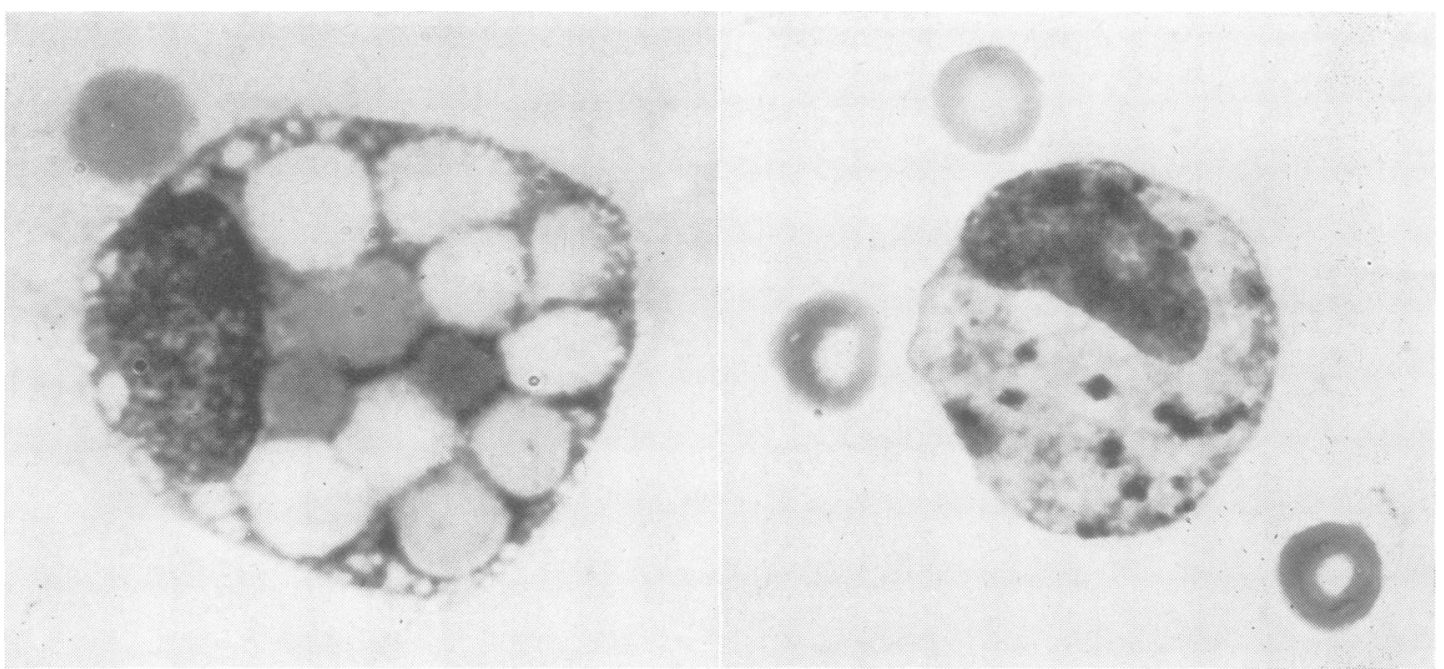

FIG. 9.

FIG. 10.

FIG. 9. An erythrophage (May-Grünewald-Giesma $\times 6,700)$.

FIG. 10. A cell containing haemosiderin (May-Grünewald-Giemsa $\times 6,700$ ).

but the monocytoids are larger and of a denser cell structure. The nucleus cannot be outlined against the cytoplasm. At times these cells have large, veillike cytoplasmic processes. The other monocytoids differ substantially in size and appearance from the round, lymphocyte-like monocytoids. They are

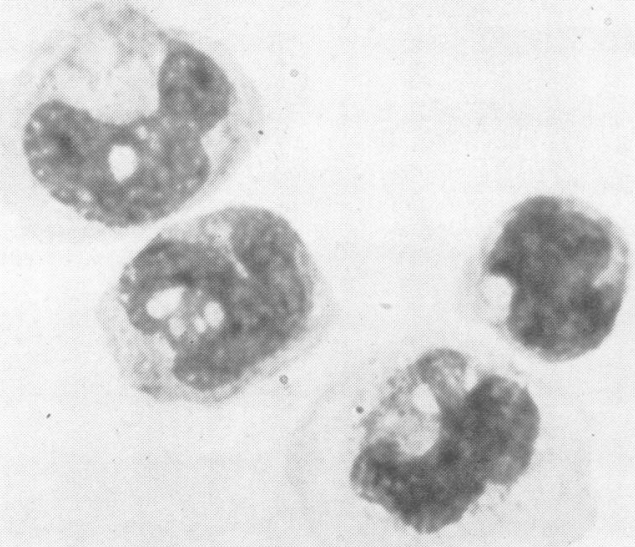

FIG. 11. Different types of monocytoids (May-GrünewaldGiemsa $\times 6,700$ ). angular, irregular and, as a rule, rich in cytoplasm. The nucleus may be large or small; it has a loose chromatin network and a well-defined nuclear membrane. Sometimes the density of the nucleus is the same as that of the cytoplasm and then it is not possible to recognize the nucleus. The cytoplasm is of the same structural appearance as that of macrophages and sometimes contains vacuoles Transitional forms between these two types of cells? and macrophages are common and can therefore be difficult to classify. On an uninterrupted observation of the cells it is possible to follow the development of a small monocytoid to a macrophage. During the process the cell gradually undergoes various modifications before it assumes a macrophagelike appearance.

The lymphocytes are of uniform appearance (Fig. 6). The nucleus often fills the entire cell. The small lymphocytes usually show no cytoplasm, while the large ones have a cytoplasmic margin. The nucleus is round, light grey with a fine chromatin network. If the sample is old, the lymphocytes are usually shrunken and have an irregular 'ragged' outline.

The neutrophils differ in appearance from the lymphocytes: they are granular and their structure is denser. Unlike the lymphocytes, they are slightly yellow (Fig. 7). The nucleus cannot be distinguished from the cytoplasm. The cells are round or pyriform. In the latter form the tapering part of the cells is slightly slit up or tail-like. In C.S.F. containing an increased number of neutrophils degenerated forms 


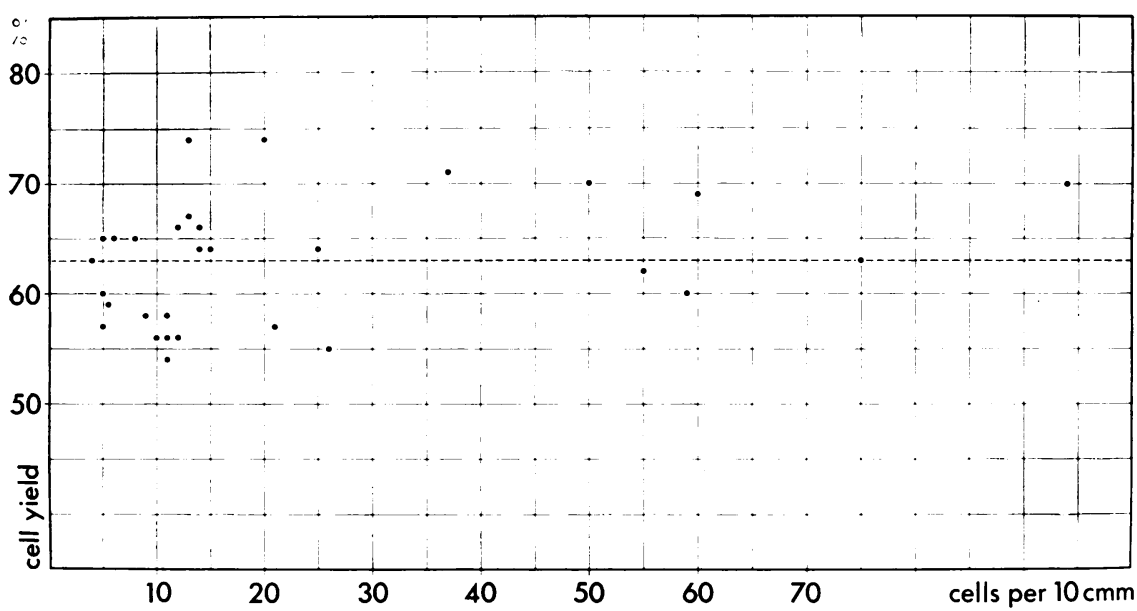

FIG. 12a.

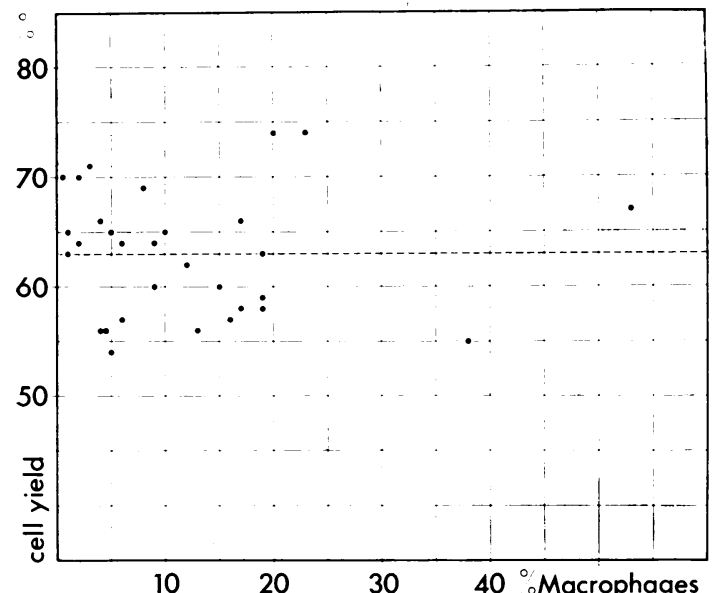

are common These cells resemble those monocytoids in which the cytoplasm cannot be distinguished from the nucleus. The degenerated neutrophil, however, has a speckled appearance and sometimes on slight variations of the focus the segmented nucleus can be discerned.

Eosinophils resemble the neutrophils but are yellower, besides which they have distinct, closely packed black granules.

The group of atypical cells is heterogeneous. It comprises all cells differing in appearance from those described above. Atypical cells, particularly tumour cells (Fig. 4), rarely occur in the C.S.F., but when they do they contrast sharply with the other types of cells and are therefore conspicuous.

Of the types of cells described, macrophages and monocytoids vary widely in morphology and cellular activity. They are therefore classified more readily
FIG. 12a. Cell yield plotted against total number of cells in 10 c.mm.

FIG. 12b. Cell yield plotted against relative number of macrophages.

FIG. $12 b$.

in phase contrast than in fixed and stained preparations.

EXAMINATION OF STAINED CELLS In May-GrünewaldGiemsa-stained preparations the cytoplasm of the macrophages stains but faintly, the nucleus fairly intensely. Phagocytosed haemosiderin appears blue-black or brown-red (Fig. 10). Haematoidin does not stain. It has the same appearance and colour as in the phase-contrast microscope, i.e., it appears as yellow-brown, rhomboid crystals.

The monocytoids usually stain well. These cells vary widely in their appearance (Fig. 11). Only a few of them resemble blood monocytes. The nucleus is tortuous, horse-shoe-shaped, rounded, kidneyshaped, crescent-shaped or pseudosegmented.Trefoilshaped nuclei are also sometimes seen. The structure of the nucleus is loose as in macrophages, or dense 
as in lymphocytes. In addition the ratio between the size of the nucleus and that of the cytoplasm varies. In some monocytoids the nucleus fills almost the entire cell. In others the nucleus is narrow and eccentric giving the cell the appearance of a signetring cell. The cytoplasm is sometimes foamy or vacuolized. Small basophilic granules can at times be seen.

The morphology of lymphocytes and granulocytes is the same as that in blood smears.

RESUlts OF STATISTICAL ANALYSIS The yield obtained by the sedimentation method was on the average about $60 \%$ and can practically always be expected to be more than $50 \%$. Staining involves a considerable loss of cells, resulting in a low yield, about $20 \%$ (Table I and Figs. 12a and $b$ ).

In the material examined the dispersal of the relative numbers of cells on four simultaneous sedimentations of a given sample and subsequent differential cell counts was not larger than could be ascribed to chance (Table II).

\section{TABLE I}

YIELD BY SEDIMENTATION METHOD ON 30 SAMPLES OF C.S.F.

\begin{tabular}{lccc} 
& $\begin{array}{c}\text { Mean } \pm S \\
(\%)\end{array}$ & \multicolumn{2}{c}{$\begin{array}{c}\text { Confidence Limits } \\
\text { for Mean } \pm 2 S_{m}\end{array}$} \\
\hline $\begin{array}{lccc}\text { After } \\
\text { sedimentation }\end{array}$ & $62.9 \pm 5.6$ & \pm 2.6 & $52-74$ \\
After staining & $21.5 \pm 6.2$ & \pm 2.9 & $10-34$
\end{tabular}

The differences between the relative numbers of cells found in the differential cell counts before and after sedimentation in the present material were not larger than could be ascribed to random fluctuations, i.e., the differential cell count performed after sedimentation for one hour reflects the true distribution of the cells in the C.S.F. (Table III).

\section{DISCUSSION}

Available methods for examination of the cells in the C.S.F. have several drawbacks. The cells are damaged either in association with concentration, fixation, or staining of the sample. The FuchsRosenthal cell counting method is not very informative, especially if the sample is poor in cells. The cell count can then be performed in a Jessen chamber (10 c.mm.) using the Fuchs-Rosenthal staining method. The differential count of cells stained by this method is apt to give unreliable results. The nuclei of the monocytoids vary widely in appearance and sometimes are tortuous or pseudosegmented. In the cell counting chamber these are often erroneously conceived as polynuclear cells.

In conventional methods for examination of the cells in the C.S.F. the samples are concentrated by centrifugation, flocculation, filtration, and sedimentation. Originally centrifugation was used (the French method of Widal and Ravaut, 1900; Widal,

TABLE II

RELIABILITY OF SEDIMENTATION METHOD

\begin{tabular}{|c|c|c|c|c|c|c|c|c|c|c|}
\hline & \multicolumn{8}{|c|}{ RELIABILITY OF SEDIMENTATION METHOD } & \multirow[b]{2}{*}{$x^{2^{3}}$} & \multirow[b]{2}{*}{$\boldsymbol{P}$} \\
\hline & $-3 S$ & $-2 S$ & $-S$ & 0 & $+S$ & $+2 S$ & $+3 S$ & $N$ & & \\
\hline Frequencies obtained ${ }^{1}$ & 1 & 7 & 30 & 4 & 23 & 9 & 2 & 76 & $3 \cdot 73$ & $>0 \cdot 20$ \\
\hline Frequencies expected ${ }^{2}$ & & & $25 \cdot 3$ & & $25 \cdot 3$ & & & & & \\
\hline
\end{tabular}

${ }^{1}$ The frequencies in the first line denote the number of differences between the calculated mean and the individual relative cell numbers for each patient according to the following classification: deviation of absolute value less than $\mathbf{S}$ : $+\mathbf{S}$ or $-\mathbf{S}$; deviation of absolute value between $S-2 S:+2 S$ or $-2 S$; deviation of absolute value between $2 S-3 S:+3 S$ or $-3 S$.

${ }^{2}$ The second line gives expected frequencies according to a normal distribution.

${ }^{3}$ The two last columns in the first line give the $\chi^{2}$ value, calculated on four groups, the outer two groups taken together and the probability of the $\chi^{2}$ value under the null hypothesis stated. Degrees of freedom $=3$.

TABLE III

COMPARISON BETWEEN THE DIFFERENTIAL CELL COUNT BEFORE AND AFTER SEDIMENTATION

\begin{tabular}{|c|c|c|c|c|c|c|c|c|c|c|c|}
\hline & & $-3 S$ & $-2 S$ & $-S$ & 0 & $+S$ & $+2 S$ & $+3 S$ & $N$ & $x^{23}$ & $\boldsymbol{P}$ \\
\hline $\begin{array}{l}\text { Frequencies } \\
\text { obtained }^{1}\end{array}$ & $\begin{array}{l}\text { Macrophages } \\
\text { Monocytoids } \\
\text { Lymphocytes }\end{array}$ & $\begin{array}{l}2 \\
0 \\
0\end{array}$ & $\begin{array}{l}7 \\
4 \\
3\end{array}$ & $\begin{array}{r}11 \\
14 \\
8\end{array}$ & $\begin{array}{l}3 \\
2 \\
4\end{array}$ & $\begin{array}{r}9 \\
11 \\
12\end{array}$ & $\begin{array}{l}4 \\
5 \\
8\end{array}$ & $\begin{array}{l}1 \\
1 \\
2\end{array}$ & $\begin{array}{l}37 \\
37 \\
37\end{array}$ & $\begin{array}{l}1 \cdot 36 \\
1 \cdot 68 \\
4 \cdot 28\end{array}$ & $\begin{array}{l}>0.70 \\
>0.50 \\
>0.20\end{array}$ \\
\hline Frequencies & & & & $12 \cdot 3$ & & $12 \cdot 3$ & & & & & \\
\hline
\end{tabular}

expected ${ }^{2}$

${ }^{1}$ The frequencies in the first three lines give the number of differences between relative cell numbers obtained before and after sedimentation according to the same classification as given in Table II.

'The fourth line gives expected frequencies according to a normal distribution.

${ }^{3}$ The two last columns in the first three lines give the same values as in Table II. Degrees of freedom $=3$. 
Sicard, and Ravaut, 1901). The method has since then been modified in various ways. Kafka (1910) and Fischer (1906) added a few drops of formalin before centrifugation, Forster (1930) added autologous serum, and Röder and Rehm (1942) egg albumen. Various times and rates of centrifugation have been tried. Junker (1951) proposed centrifugation for two minutes at a low rate and Lumsden (1960) recommended centrifugation at a low temperature. Centrifugation damages the cells and therefore results in unsatisfactory cytological pictures (Sayk, 1960; and others). In personal experiments the injurious effect of centrifugation of the C.S.F. at different rates and for different periods of time at room temperature and at low temperature $\left(+4^{\circ} \mathrm{C}\right.$.) with and without the addition of autologous serum or commercially available gamma globulin (Kabi) was studied in phase contrast. The cells most susceptible to injury by centrifugation were the macrophages. On centrifugation, using the French method $(1,200$ to 2,000 r.p.m. for 10 minutes), the macrophages were completely destroyed. Centrifugation according to Junker (1951) (600 r.p.m. for two minutes) damaged the macrophages which were then difficult to identify. The other types of cells tolerated centrifugation better, but in phase contrast many 'round cells' were often seen to be angular or contracted, changes which were not seen in the corresponding sedimentation preparations. The severity of cellular damage varied with the strength of centrifugation. The damage was equally severe in unprepared and prepared samples and it was not less when the samples were centrifuged at low temperatures.

Alzheimer's flocculation method (1907) is said to produce satisfactory histological preparations (Cotton and Ayer, 1908; Bannwarth, 1933), but it is too laborious for routine use. According to Bannwarth, fixation with alcohol results in contraction of the cells with secondary changes in the chromatin network. Ostertag's method (1932) has essentially the same inherent sources of error. Simon and Schörer's 'cell catch' procedure (1963) results in considerable deformation of cells, particularly of the macrophages, when the jelly-like substance in which the cells are embedded is compressed under high pressure.

Sedimentation for 24 hours, as recommended by Ravaut, cannot be used for concentration because practically all cells either die or undergo such changes that they can no longer be identified. Sedimentation for six hours (Schönenberg, 1949) also gives unsatisfactory results. On examination in phase contrast most of the macrophages are dead. Many monocytoids and lymphocytes also die.

Filtration through a millipore filter (Seal, 1956) yields the largest percentage. This method of con- centration is rapid and simple. Its use is limited by the sensitivity of the filter to many solutions conventionally used for haematological-histological fixation and staining. Therefore May-GrünewaldGiemsa staining cannot be used. The cytological quality of specimens prepared with a millipore filter is, however, unsatisfactory. The macrophages are severely damaged. Many other cells are difficult to identify as they are partly hidden in the filter substance. According to Eneström (1966), the cells are deformed and shrivelled owing to adhesion and the cells resemble those in centrifuged samples. Tumour cells, however, are well preserved by this method. It can therefore be used for demonstrating tumour cells in the C.S.F. (Stormby, personal communication).

Müller and von Döbeln (1948) recommended examination of C.S.F. cells in the phase-contrast microscope to avoid the difficulties involved in fixation and staining. Junker (1951) used this method in an investigation of untreated C.S.F. rich in cells and was able to identify macrophages, monocytoids, lymphocytes, and neutrophils.

The phase contrast method can with advantage be used for counting the cells in a counting chamber. The results on C.S.F. samples poor in cells are much more reliable than those obtained with the Fuchs-Rosenthal method because the sample is not diluted and because it is much easier to recognize the cells. In C.S.F. rich in cells $(>100$ cells per counting chamber) a complete differential cell count can be made in the same way as in sedimentation preparations. A close study of the individual cells is, however, not possible because the cellular details cannot be recognized as well as under a water immersion lens.

Of available methods, the sedimentation procedure by the method of Sayk (1960) and the suction chamber by that of Eneström (1963) appear to be the best. They are gentle, technically simple, and not laborious. Used by the present author these methods were found to have several disadvantages. Suction produced in the floor of the chambers, in Sayk's chamber by means of a filter paper and in Eneström's by under-pressure outside the chamber, results in only poor adhesion of the lymphocytes and granulocytes to the slide in the bottom of the chamber. The large cells (macrophages and monocytoids) adhere better to the glass and remain there, with consequent overrepresentation of macrophages and monocytoids in the differential cell count. In addition, many cells are damaged by the slow drying in the final phase of the sedimentation. Characteristic of Eneström's and of Sayk's method are the morphological changes occurring in the macrophages. The nucleus and the cytoplasm in their preparations 
differ substantially in appearance from that of the living macrophage seen in sedimentation preparations in phase contrast. The border of the cytoplasm is rounded, the cell appears slightly oedematous, and the nucleus is severely changed, it becomes angular and large. In many of the cells Sayk finds morphological changes which he conceives as 'alten veränderten Zellen'. On the average $14 \%$ of the cells show 'erhebliche Altererscheinungen'.

With Sayk's method, plasmocytic or plasma cells have been demonstrated in various neurological diseases. In my opinion, plasma cells are rarely seen in the C.S.F. The conversion of lymphocytes to plasma-cell-like cells can be followed by the phase contrast examination of C.S.F. sediments obtained by the method described. On prolonged microscopic examination lymphocytes and also monocytoids in the periphery of the preparation swell with eccentric displacement of the nucleus and the appearance of perinuclear halos (Fig. 13). In MayGrünewald-Giemsa-stained preparations these cells resemble plasma cells. The changes described are due to the gradual drying, in the periphery, of the preparation because of changes in surface tension during the passage of the objective across the slide. Movement of the objective to the margin of one side of the preparation is accompanied by a corresponding movement of the bulk of the fluid. The cells on the other side are then bathed in only a thin layer of C.S.F., which gradually evaporates. Here, then, the physical conditions are the same as those at the end of sedimentation in Sayk's chamber.

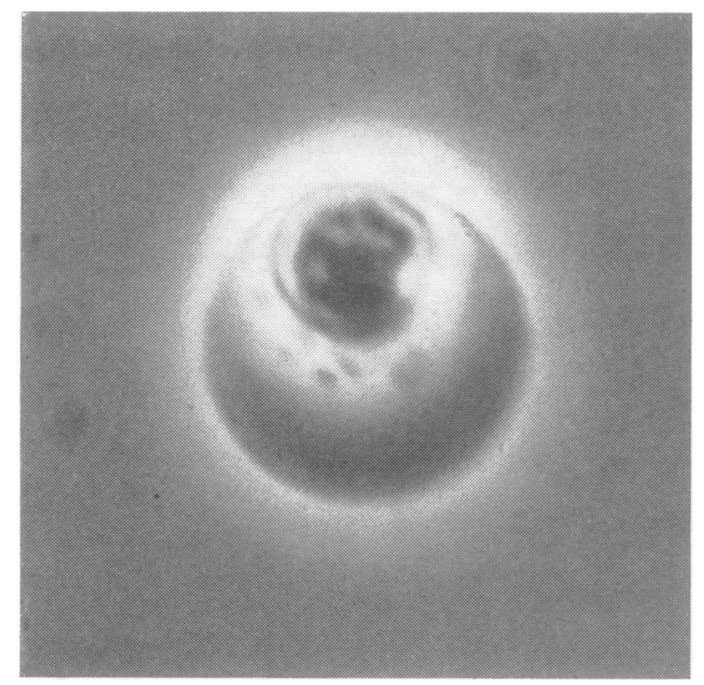

FIG. 13. A lymphocyte which has converted to a plasmacell-like cell by gradual drying (phase contrast $\times 2,500)$.
If drying is prevented by the addition of C.S.F. no plasma-cell-like cells appear. If the sample is fresh and the cells have been covered with sufficient C.S.F., the examination will rarely reveal any dead or degenerated cells. In rapidly air-dried preparations stained with May-Grünewald-Giemsa the cells are morphologically well preserved. The 'ageing' changes and the occurring of plasma cells described by Sayk are thus changes due mainly to the slow drying of his preparations.

As to the yield, Sayk claims that he can isolate 50 to $60 \%$ of the cells present with his sedimentation chamber method. Bischoff (1961) gives no percentage but says 'dass man auf ein Objektträger eine erhebliche Zahl_günstigenfalls mehrere hundertgut erhaltene Zellen zu Gesicht bekommt'. Bammer (1963) states that his modification of Sayk's method gives a 20 to $30 \%$ yield. Eneström claims that repeated sedimentation of the same sample with the suction chamber method will give a yield of 80 to $90 \%$ of the cells (personal communication). None of the authors, however, report how they calculate respective yields. The percentages given by Sayk and Eneström are surely too high. During the treatment to which the cells are subjected before the results are obtained many cells are washed off the slide.

The method described by the present author is suitable for routine cytological examination of the C.S.F. The sedimentation chamber is so simple that preparation of even large series requires but little time. This enables examination of several samples in rapid succession. The technique is simple and not laborious. After sedimentation the C.S.F. can be used for further analysis. The cells are not damaged and they are readily identified in the phasecontrast microscope. The differential cell count of the sedimented cells gives a representative cytological picture, i.e., it reflects the true distribution of the cells. A disadvantage of the method is the low yield in May-Grünewald-Giemsa-stained preparations, about $20 \%$, which, however, is of less importance because the cell yield before staining at the phase-contrast examination is large, namely about $60 \%$. With this method, then, it is possible more closely to follow the cytological process in the C.S.F. in various neurological diseases. As a rule, a differential cell count in the phase-contrast microscope is sufficient. Staining can be done if it is desired to store the preparation, or to study in detail the monocytoids, or if atypical cells are seen. Rapid air-drying of the sediment prevents degenerative changes of the cells, which show up well in the stained preparations. Tumour cells are readily recognized in the phase-contrast microscope so that the method can with advantage be used for screening tumour cells in C.S.F. 


\section{SUMMARY}

A routine method is described for cytological examination of the C.S.F. The method provides a representative and reliable differential cell count.

The investigation was supported by the Medical Faculty of the University of Lund, the Swedish Multiple Sclerosis Society, and Anders Österlunds Foundation, Malmö, Sweden.

The statistical analysis was performed in consultation with Professor C.-E. Quensel, Department of Statistics, University of Lund, Sweden.

\section{REFERENCES}

Alzheimer, A. (1907). Einige Methoden zur Fixierung der zelligen Elemente der Cerebrospinalflüssigkeit. $\mathrm{Zbl}$. Nervenheilk. Psychiat., 18, 449-451.

Bammer, H. (1963). Zur Tumorzelldiagnostik im Liquor cerebrospinalis. Dsch.Z. Nervenheilk., 185, 89-109.

Bannwarth, A. (1933). Die Zellen der Cerebrospinalflüssigkeit. Arch. Psychiat. Nervenkr., 100, 533-573.

Bischoff, A. (1961). Erfahrungen mit der Tumorzelldiagnostik im Liquor cerebrospinalis. Acta Neurochir. (Wien), 9, 510-524.

Cotton, H. A., and Ayer, J. B. (1908). The cytological study of the cerebro-spinal fluid by Alzheimer's method, and its diagnostic value in psychiatry, Rev. Neurol. Psychiat., 6, 207-228.

Eneström, S. (1963). Suction technique for sedimentation of body fluid cells. Acta path. microbiol. scand., 59, 473-480.

- (1965). Some aspects on technique and clinical evaluation of CSF cytology. Acta neurol. scand., 41, suppl. 13, pp. 153-159. (1966). Die Saugkammermethode. In Symposion über die
Zerebrospinal-flüssigkeit, 1964, Rostock, ed. J. Sayk, pp. 23-33. Fischer, Jena.

Fischer, O. (1906). Klinische und anatomische Beiträge zur Frage nach den Ursachen und der Bedeutung der zerebrospinale Pleocytose. J. Psychiat. Neurol., 27, 313-359.

Forster, E. (1930). Die Bedeutung der Liquorzellbildes für die Diagnostic der Tumoren des Zentralnervensystems, und die vom Plexus und den Meningen ausgehenden Tumoren, $Z$. ges. Neurol. Psychiat., 126, 683-720.

Fuchs A. and Rosenthal, R. (1904). Physikalisch-chemische, zytologische und anderweitige. Untersuchungen der Zerebrospinalflüssigkeit. Wein. med, Presse., 45, 2082-2087.

Junker, F. (1951). Die Zellen des Liquor cerebrospinalis im Phasenkontrastmikroskop. Dsch. $Z$. Nervenheilk., 166, 237-246.

Kafka, V. (1910). Uber Technik und Bedeutung dercytologischen. Untersuchung des Liquor cerebrospinalis. Mschr. Psychiat. Neurol., 27, 414-438.

Lumsden, C. E. (1960). Problems in the cytology of cerebrospinal fluid. Arch. De Vecchi Anat. pat., 31, 319-338.

Müller, R., and von Döbeln, W. (1947). Cytological examination of the cerebrospinal fluid by means of the phase contrast microscope. Acta Psychiat. Neurol., Suppl. 46, pp. 226-239.

Ostertag, B. (1932). Die diagnostische Auswertung des Liquorzellbildes und dessen Gewinnung mittels neuer Methoden. Klin. Wschr., 11, 862-864.

Röder, F., and Rehm, O. (1942). Die Cerebrospinalflüssigkeit. Springer, Berlin.

Sayk, J. (1960). Cytologie der Cerebrospinalflüssigkeit. Fischer, Jena. Schönenberg, H. (1949). Eine einfache Methode zur Herstellung gut differenzierbarer Liquorzellpräparate. Dsch. med.Wschr., $74,881$.

Seal, S. H. (1956). A method for concentrating cancer cells suspended in large quantities of fluid. Cancer (Philad.), 9, 866-868.

Simon, G., and Schörer, H. (1963). Ein neues Verfahren zur vollständigen Erfassung der im cerebrospinalis vorhandenen Zellen (Zellenfangverfahren). Arch. Psychiat. Nervenkr., 204, 74-85.

Widal, I., Sicard, L., and Ravaut, G. (1901). Cytologie du liquide céphalo-rachidien au cours de quelques processus méningés chroniques. Bull. Soc. Méd. Hop. Paris, 3 sér., 18, 31-33. 